Водные биоресурсы и среда обитания

2019, том 2, номер 2, с. 91-95

http://journal.azniirkh.ru, www.azniirkh.ru ISSN 2618-8147 print, ISSN 2619-1024 online

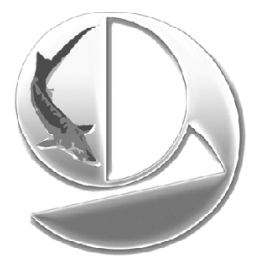

Aquatic Bioresources \& Environment

2019, vol. 2, no. 2, pp. 91-95

http://journal.azniirkh.ru, www.azniirkh.ru

ISSN 2618-8147 print, ISSN 2619-1024 online

\title{
Иформационные сообщения
}

\section{ВЕДУЩИЙ СПЕЦИАЛИСТ РЫБОПЕРЕРАБАТЫВАЮЩЕЙ ПРОМЫШЛЕННОСТИ, УЧЕНЫЙ И ПРЕПОДАВАТЕЛЬ ВИННОВ АЛЕКСЕЙ СЕРГЕЕВИЧ}

\author{
(C) 2019 С. Л. Чернявская, Л. М. Есина
}

Всероссийский научно-исследовательский институт рыбного хозяйства и океанографии (ФГБНУ «ВНИРО»), Азово-Черноморский филиал ФГБНУ «ВНИРО» («АзНИИРХ»), Ростов-на-Дону 344002, Россия

E-mail: chernyavskaya_s_l@azniirkh.ru

\begin{abstract}
Аннотация. Алексей Сергеевич Виннов (25.05.1958 - 04.06.2019 гг.) — кандидат технических наук, доцент, талантливый преподаватель, ректор Керченского морского технологического института с 2000 по 2005 г. (КМТИ), старший научный сотрудник ФГБНУ «Южный научно-исследовательский институт рыбного хозяйства и океанографии» (ЮгНИРО), заместитель директора по производству и качеству ООО «Аквамарин». А.С. Виннов внес огромный вклад в развитие образования и науки рыбной отрасли. Свою трудовую деятельность Алексей Сергеевич начал в должности младшего научного сотрудника Астраханского технического института рыбной промышленности и хозяйства, успешно защитив в 1988 г. кандидатскую диссертацию. Большую часть своей трудовой деятельности он посвятил Керченскому государственному морскому технологическому университету, проработав здесь 21 год в должностях от старшего преподавателя кафедры технологии рыбных продуктов, доцента, декана технологического факультета, проректора по учебной работе до ректора университета. А.С. Виннов обладал рациональным мышлением, был очень грамотным, тактичным человеком, умелым руководителем. Научная деятельность Алексея Сергеевича была посвящена изучению вопросов усовершенствования технологии рыбных консервов, рыбных белковых масс, кинетики ферментативного гидролиза, а также многим другим. За личный вклад в развитие образования и рыбной отрасли, за высокий профессионализм А.С. Виннов был удостоен ряда почетных знаков отличия.
\end{abstract}

Ключевые слова: Виннов Алексей Сергеевич, почетный работник рыбного хозяйства, ректор, КГМТУ, рыболовство, технология рыбопереработки, кинетика ферментативного гидролиза

\section{LEADING SPECIALIST OF FISH PROCESSING INDUSTRY, SCIENTIST AND LECTURER VINNOV ALEKSEY SERGEEVICH}

\author{
S. L. Chernyavskaya, L. M. Esina
}

Russian Federal Research Institute of Fisheries and Oceanography (FSBSI “VNIRO”), Azov-Black Sea Branch of the FSBSI “VNIRO” (“AzNIIRKH”), Rostov-on-Don 344002, Russia

E-mail: chernyavskaya_s_l@azniirkh.ru 


\begin{abstract}
Aleksey Sergeevich Vinnov (25.05.1958 - 04.06.2019) was a Candidate of Sciences (Engineering), an Associate Professor, a talented lecturer, a rector of the Kerch Maritime Technological Institute (KMTI) in 20002005, a Senior Researcher in the FSBSI "Southern Scientific Research Institute of Marine Fisheries and Oceanography" (YugNIRO), and a Deputy Head for Operation and Quality of the Limited Liability Company under the Laws of Russian Federation "Aquamarine". A.S. Vinnov made a great contribution into the development of education and science in the field of fisheries. Aleksey Sergeevich began his professional life as a Junior Researcher in the Astrakhan Technical Institute of Fishing Industry and Economy and defended his Candidate's Thesis in 1988. He dedicated the major part of his working career to the Kerch State Maritime Technological University, where he had been employed for 21 years, taking positions from a senior lecturer of the Department of Fish Processing Technology, an Associate Professor, the Dean of the Technological Faculty, the vice-rector for academic affairs, to the rector of the University. A.S. Vinnov was known for his rational thinking and professional integrity; he was diplomatic and considerate, and proved to be a competent leader. Vinnov's research works were dedicated to the issues of development of production technology for canned fish and fish protein mass, of kinetics of enzymatic hydrolysis, and many other subjects. A.S. Vinnov was honored with several badges of distinction due to his high professional expertise and personal contribution to the development of fisheries field, particularly education.
\end{abstract}

Keywords: Vinnov Aleksey Sergeevich, honored worker of fisheries, rector, KSMTU, fishing, fish processing technology, kinetics of enzymatic hydrolysis

Жизнь Алексея Сергеевича была связана с рыбной отраслью с самого рождения. Он родился в славном рыбацком городе Керчи, его отец Сергей Сергеевич Виннов стоял у истоков развития и становления рыбной промышленности Южного бассейна. В составе экипажа БМРТ «Жуковский» Сергей Сергеевич принимал участие в первой научно-промысловой экспедиции в неизученную зону Атлантического океана, был участником промысловых рейсов китобойных флотилий «Слава» и «Советская Украина».

Пойдя по стопам отца, Алексей Сергеевич поступил в Астраханский технический институт рыбной промышленности и хозяйства (1975-1980 гг.). Обладая пытливым умом, он старался найти новые современные решения в области переработки рыбного сырья, опираясь на фундаментальные знания, полученные в студенческие годы от своих известных преподавателей и ученых В.В. Баля, А.П. Черногорцева. Алексей Сергеевич впитывал новую информацию, «как губка», делал это с удовольствием, всегда был открыт для знаний. В 1980 г. им был получен диплом с отличием по специальности «Технология рыбных продуктов».

Свою трудовую деятельность Алексей Сергеевич начал в должности младшего научного сотрудника в институте, где учился. Результатом его плодотворной работы стала защита кандидатской диссертации на тему «Способ переработки рыбных подпрессовых бульонов» по специальности «Технология мясных, молочных и рыбных продуктов» (1988 г.) [1].
После защиты кандидатской диссертации Алексей Сергеевич возвращается в родную Керчь. Большую часть своей трудовой деятельности он посвятил Керченскому государственному морскому технологическому университету, где проработал 21 год. В этом университете (ранее - Керченский филиал Калининградского технического института рыбной промышленности и хозяйства) Алексей Сергеевич начал свою работу с должности старшего преподавателя кафедры технологии рыбных продуктов.

Алексей Сергеевич обладал рациональным мышлением, был очень грамотным, тактичным человеком, умелым руководителем. В 1992 г. его назначают деканом технологического факультета, a уже в 1995 г. — проректором по учебной работе, с 2000 г. Алексей Сергеевич - ректор Керченского морского технологического института (позже Керченского государственного морского технологического университета).

Многим запомнился Алексей Сергеевич именно в должности ректора. За 5 лет (с 2000 по 2005 г.) А.С. Виннов сделал все возможное, чтобы студенты морского факультета смогли прибрести необходимые практические навыки в учебных рейсах на парусном судне «Херсонес»; началась работа над созданием учебно-тренажерного центра для дополнительной профессиональной подготовки членов экипажей морских судов и студентов; начал свою работу научно-практический журнал «Рыбное хозяйство Украины»; активизировалась международная деятельность института, появились про- 


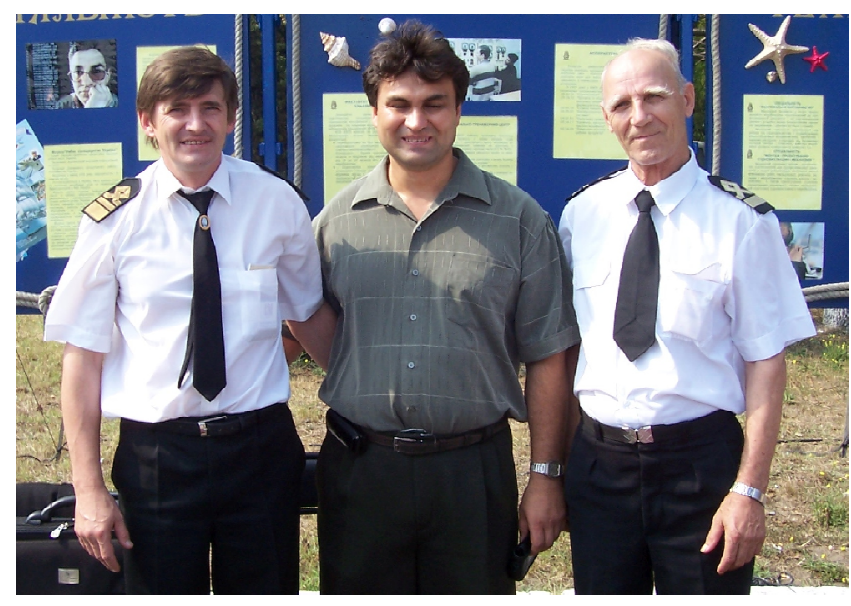

Презентация стендов КГМТУ на День города Керчи, 2004 г. (слева направо: Виннов А.С., ректор КГМТУ; Попов В.В., аспирант кафедры судовых энергетических установок; Мудрый А.М., проректор по административно-хозяйственной работе)

KSMTU exhibition stands, City Day, Kerch 2004 (from left to right: Vinnov A.S., rector of KSMTU; Popov V.V., Postgraduate student of the Chair of Ship Power Plants; Mudry A.M., vice-rector of administrative activities)

граммы по обмену студентами; введена единая форма студентов и преподавателей и многое другое.

С 2006 по 2009 г. Алексей Сергеевич продолжал трудиться в университете в должности доцента кафедры «Технологии и химии морепродуктов» с исполнением обязанностей заведующего этой кафедрой. Он всегда старался привлечь грамотных специалистов, которые могли передать свой бесценный опыт студентам. Под его руководством на кафедре длительное время работали такие ученые и преподаватели, как к. т. н. Н.И. Егорова, к. б. н. С.Г. Пученкова, к. т. н. (впоследствии д. б. н.) Е.В. Сухаренко, к. х. н. Н.И. Андрейкина, к. х. н. В.В. Алябьева и другие.

За личный вклад в развитие образования и рыбной отрасли, за высокий профессионализм в 2001 г. Алексей Сергеевич Виннов был удостоен почетного звания «Заслуженный работник образования Автономной Республики Крым», в 2004 г. награжден знаком «Отличник образования Украины», в 2005 г. - почетным знаком отличия «Почетный работник рыбного хозяйства», в 2016 г. ему присвоено членство Афинского Института образования и исследований (Academic Member of Athens Institute for Education and Research, belonging to the Agricultural Research Unit and the Marketing Research Unit).

C 2009 г. Алексей Сергеевич продолжил свою работу в сфере образования доцентом кафедры
«Технология мясных, рыбных и морепродуктов» в Национальном университете биоресурсов и природопользования Украины (г. Киев).

Он всегда оказывал большую консультативную помощь молодым ученым, аспирантам и студентам. С благодарностью за поддержку его вспоминает не одно поколение студентов.

Алексей Сергеевич непрестанно учился сам и помогал молодым ученым, он был руководителем аспирантов В.В. Богомоловой, Т.Н. Маевской, консультантом аспирантов Е.В. Сухаренко, О.Н. Кривонос.

На протяжении всей жизни Алексей Сергеевич не уставая изучал научную литературу, интересовался новыми публикациями (статьями, патентами), очень быстро усваивал и мог в точности и очень подробно передать содержание прочитанной им специализированной литературы. Он бескорыстно делился со студентами и коллегами своим большим запасом книг и различных публикаций в электронном виде.

В 2014 г. Алексей Сергеевич вернулся из Киева в Крым и работал на кафедре технологии Крымского агротехнического университета (г. Симферополь). С 2015 по 2017 г. А.С. Виннов работал в должности старшего научного сотрудника лаборатории технологических исследований, нормирования и технического регулирования ФГБНУ «Южный научно-исследовательский институт рыбного хозяйства и океанографии» (позже отдел «Керченский» Азово-Черноморского филиала ФГБНУ «ВНИРО» («АзНИИРХ»).

Алексей Сергеевич был очень общительным и всесторонне развитым человеком, он с удовольствием принимал активное участие в различных конференциях, семинарах, выставках.

Алексей Сергеевич всегда был сторонником не поверхностного изучения проблемы, а поиска ее истинных причин, часто выдвигал массу гипотез и проверял их в ходе экспериментов, радовался, когда получались хорошие результаты, и искренне расстраивался, если опыт не удавался.

Научная деятельность Алексея Сергеевича была посвящена изучению вопросов усовершенствования технологии рыбных консервов, рыбных белковых масс, кинетики ферментативного гидролиза, а также многим другим [2-5]. В обсуждениях с ним всегда «рождались» новые идеи, выявлялись особенности новых технологий, строились перспективы дальнейшей работы. 


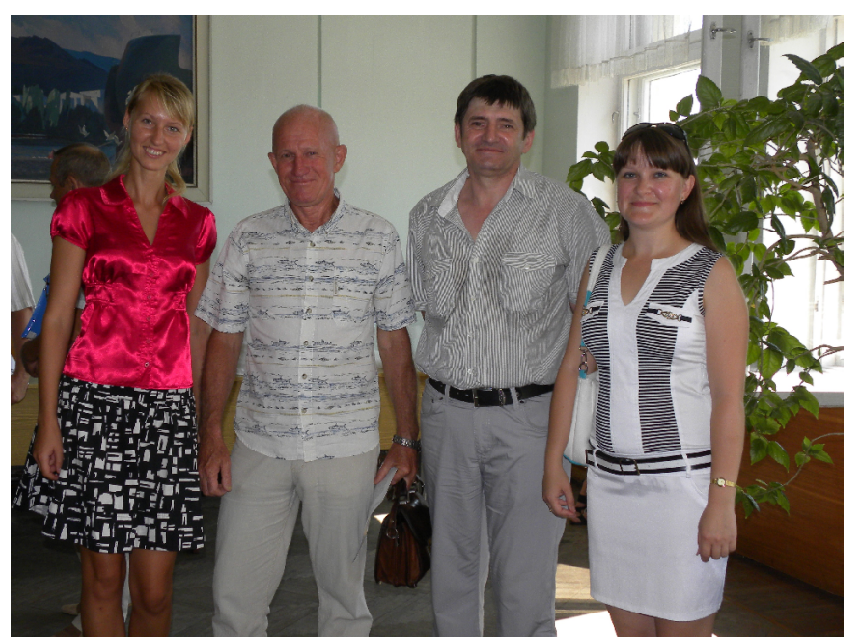

Участники VIII Международной научно-практической конференции «Современные рыбохозяйственные и экологические проблемы АзовоЧерноморского региона», организованной в г. Керчь, ФГБНУ «ЮгНИРО» 26-27 июня 2013 г. (слева направо: Чернявская С.Л., Кухарев Н.Н., Виннов А.С., Богомолова В.В.)

Participants of the $8^{\text {th }}$ International Scientific and Practical Conference "Current Fishery and Environmental Problems of the Azov-Black Sea Region", held by the FSBSI "YugNIRO" in Kerch on 26-2 $7^{\text {th }}$ of June, 2013 (from left to right: Chernyavskaya S.L., Kukharev N.N., Vinnov A.S., Bogomolova V.V.)

Полученная в университете квалификация инженера-технолога особенно проявилась, когда с помощью инженерных расчетов и «золотых рук» Алексея Сергеевича в лаборатории появилось технологическое оборудование для производства кормовой продукции. Он хорошо разбирался в устройстве как технологического, так и лабораторного аналитического оборудования, легко осваивал работу на новых приборах, компьютерные программы и учил этому своих коллег.

С 2017 по 2019 г. Алексей Сергеевич работал заместителем директора по производству и качеству ООО «Аквамарин» (г. Севастополь). Большое внимание уделялось им снижению себестоимости продукции, разработке нового ассортимента, улучшению качественных характеристик продукции.

Результатом 33-летней работы Виннова Алексея Сергеевича стало более 50 научных публикаций, не считая многочисленных методических указаний к лекционным, лабораторным и практическим занятиям студентов. Алексей Сергеевич является соавтором учебного пособия «Технология производства соленой рыбы» [6].

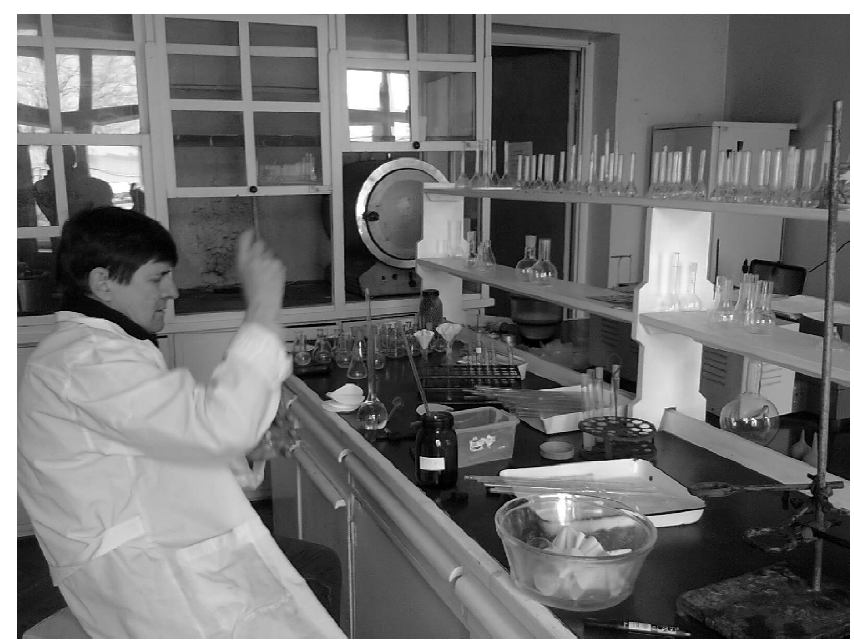

Алексей Сергеевич Виннов за работой в лаборатории ФГБНУ «ЮгНИРО» (2015 г.)

Aleksey Sergeevich Vinnov at his working place in the laboratory of the FSBSI "YugNIRO" (2015)

Алексей Сергеевич был очень эрудированным человеком, отлично владел английским языком (в т. ч. техническим), очень много читал, особенно любил творчество братьев Стругацких, интересовался культурой народов мира, часто с некоторой ностальгией вспоминал поездки во Францию, свою работу в Африке.

Он был ответственным, глубоко порядочным человеком, прекрасным семьянином. В браке с женой Фаридой Рафатовной Алексей Сергеевич прожил 37 лет, воспитав прекрасного сына Руслана.

После тяжелой и продолжительной болезни 4 июня 2019 г. на 62-м году ушел из жизни Алексей Сергеевич Виннов - кандидат технических наук, доцент, один из ведущих специалистов рыбоперерабатывающей промышленности. Коллектив Азово-Черноморского филиала ФГБНУ «ВНИРО» («АзНИИРХ») разделяет боль утраты с родными и близкими.

Читающим эти строки хочется пожелать ценить жизнь во всех ее проявлениях, беречь своих любимых и родных людей, побольше проводить с ними время, чаще посещать любимые места, и, конечно, своей работой развивать науку и образование, чтобы ваши достижения и открытия были фундаментальными и смогли сделать жизнь людей лучше.

\section{СПИСОК ЛИТЕРАТУРЫ}

1. Виннов А.С. Способ переработки рыбных подпрессовых бульонов : дис. ... канд. техн. наук. Астрахань, 1988. $167 \mathrm{c}$. 
2. Богомолова В.В., Виннов А.С. Усовершенствование технологии рыбных консервов с применением гидроколлоидов // Труды ЮгНИРО. 2013. Т. 51. C. $150-152$.

3. Маевская Т., Виннов А. Микроструктура гелей из сурими карпа // Продовольча індустрія АПК. 2013. T. 5, № 25. С. 18-23.

4. Виннов А.С. Торможение ферментативного гидролиза белковых веществ в субстратах из черноморской атерины // Продовольча індустрія АПК. 2014. T. 1, № 27. C. 18-22.

5. Vinnov A.S., Chernyavskaya S.L., Krivonos O.N. The Azov anchovy proteins enzymatic hydrolysis modes development // Труды ЮгНИРО. 2017. Т. 54, № 2. C. 133-138.

6. Долганова Н.В., Першина Е.В., Виннов А.С. Технология производства соленой рыбы : учеб. пособие. СПб: ГИОРД, 2018. 293 с.

\section{REFERENCES}

1. Vinnov A.S. Sposob pererabotki rybnykh podpressovykh bul'onov : dis. ... kand. tekhn. nauk [Method of fish stickwater processing. Candidate's (Technology) Thesis]. Astrakhan, 1988, 167 p. (In Russian).
2. Bogomolova V.V., Vinnov A.S. Usovershenstvovanie tekhnologii rybnykh konservov s primeneniem gidrokolloidov [Improvement of fish preserve technology with the use of hydrocolloids]. Trudy YugNIRO [YugNIRO Proceedings], 2013, vol. 51, pp. 150-152. (In Russian).

3. Maevskaya T., Vinnov A. Mikrostruktura geley iz surimi karpa [Microstructure gels carp surimi]. Prodovol'cha industriya APK [Food Industry of AIC], 2013, vol. 5, no. 25, pp. 18-23. (In Russian).

4. Vinnov A.S. Tormozhenie fermentativnogo gidroliza belkovykh veshchestv v substratakh iz chernomorskoy ateriny [Assessment of proteins enzymatic hydrolysis diffusion inhibition in the substrates on the basis of the Black Sea atherine]. Prodovol'cha industriya APK [Food Industry of $A I C], 2014$, vol. 1, no. 27, pp. 18-22. (In Russian).

5. Vinnov A.S., Chernyavskaya S.L., Krivonos O.N. The Azov anchovy proteins enzymatic hydrolysis modes development. Trudy YugNIRO [YugNIRO Proceedings], 2017, vol. 54, no. 2, pp. 133-138.

6. Dolganova N.V., Pershina E.V., Vinnov A.S. Tekhnologiya proizvodstva solenoy ryby: ucheb. posobie [Technology of salted fish production. A study guide]. Saint-Petersburg: GIORD, 2018, 293 p. (In Russian).

Поступила 21.06.2019

Принята к печати 27.06.2019 